DOI: http://dx.doi.org/10.33846/hn50204

http://heanoti.com/index.php/hn

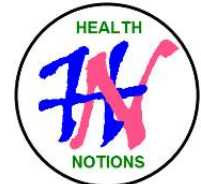

RESEARCH ARTICLE

URL of this article: http://heanoti.com/index.php/hn/article/view/hn50204

\title{
The Influence of Age and Nutritional Status on Heat Strains Incident on Workers of Brem Making in Kaliabu Village, Madiun
}

\author{
Siska Wahyu Handayani ${ }^{1(\mathrm{CA})}$, Sri Hernawati ${ }^{2}$, Farida Wahyu Ningtyias ${ }^{3}$ \\ ${ }^{1(\mathrm{CA})}$ Master Student of Public Health Science, Universitas Jember, Indonesia; siskabidan6@ gmail.com \\ (Corresponding Author) \\ ${ }^{2}$ Faculty of Dentistry, Universitas Jember, Indonesia; srihernawati.drg5@yahoo.com \\ ${ }^{3}$ Faculty of Public Health, Universitas Jember, Indonesia; farida_wahyuningtyas@yahoo.com
}

\begin{abstract}
Workers at brem industries are particularly at risk of heat strains at work. This is due to the age factor of the workers as well as the nutritional status that can be the main cause in case of heat strain events. Purpose of this study was to find out the level of influence of age factor and nutritional status on heat strain events in brem industries workers in Kaliabu village, Madiun. Quantitative observational analytical research with a cross sectional approach where the sample of research amounted to 157 respondents from a total population of 266 workers. Regression test with Amos 23 tools in analyzing data. Result in the age variable was 0.072 and for the nutritional status obtained the result of 0.079 against the incidence of heat strains where both variables had a significant influence on heat strains. So that the need for spatial planning and fulfillment of good nutrition by industry managers.
\end{abstract}

Keywords: heat strain; nutritional status; age; brem; industries

\section{INTRODUCTION}

Heat Strain is a term used to describe the effects that occur on the body due to exposure to heat pressure. The core temperature of the human body is maintained at about $37^{\circ} \mathrm{C}$. Too high human body temperature can interfere with the body's chemical reactions as well as the structure and function of proteins. A serious health threat to the workforce in a hot environment is the occurrence of thermal strain disorders. ${ }^{(1)}$ Heat strains are characterized by an increase in body temperature of more than $38^{\circ} \mathrm{C}$. Reactions that occur such as vasodilation, heart rate increase, skin temperature increases, and the core temperature of the body initially decreases to increase. Continued exposure to heat can increase the risk of health disorders due to the hot working climate. Excessive heat strains can also lose weight. Body temperature is one way of monitoring heat strains. Body temperature drops more slowly than heart rate when exposed to heat pressure. Body temperature measurements are performed in oral, tympanic and rectal membranes.

Workers who experience heat strains will decrease performance that will also impact productivity. A year 1979 in America, cases of heat strains caused workers to not enter for at least one day were estimated at 1,432 cases. Cases of heat illness per 100,000 workers in plantation areas (9.16 cases/100,000 workers), construction (6.36 cases/100,000 workers), and mines (5.01 cases/100,000 workers), other research on 145 workers showed the group was at risk of $22.1 \%$ and $11 \%$ experienced heat strains ${ }^{(2)}$.

Workers' body temperatures were found to be higher than the permitted exposure limits. Indicates about Heat Strain borne by workers is quite significant whereas pulse and blood pressure are found to be normal \& not exceeding the limit. ${ }^{(3)}$ Aluminium smelting stated that most participants $(54 \%)$ have 1 or more heat strain signs. ${ }^{(4)}$ Incidence measurements of the hot working climate at three locations were $32.4{ }^{\circ} \mathrm{C}, 33.6{ }^{\circ} \mathrm{C}$ and $32.1{ }^{\circ} \mathrm{C}$, respectively, indicating that workers exposed to heat strains had a significant association with heat strain events ${ }^{(5)}$.

Explained about workers who are exposed heat pressure experience subjective complaints of heat strains such as dizziness, cramps or muscle stiffness, fatigue, weakness, and increased sweat production and workers who are in a work environment with temperature exceeding the threshold value experience heat strain complaints such as fatigue $50 \%$, dizziness $27.8 \%$, and stiff or muscle cramps $11.1 \%$. $^{(6)}$ Workers at factory, Sumedang District Medan Polonia showed results that in a long period of time hot working climate received by workers can affect the incidence of heat strains. ${ }^{(7)}$ Some of individual factors that affect heat strains include age, sex, obesity, acclimatization, alcohol consumption and drug consumption. ${ }^{(8)}$ 
Workers who are exposed to heat for extended periods time can also cause heat strains. Heat strains are the body's physiological response to heat pressure received by a person. ${ }^{(9)}$ Heat strain indicators include high body temperature, pulse rate, blood pressure, sweating, and weight loss. Heat strains that last continuously and are not handled properly can manifest into health problems due to heat pressures such as dehydration, heat rash, heat syncope, heat cramps, heat exhaution, and heat stroke. Symptoms and signs of disease due to heat exposure need to be detected early before it appears disease caused by heat exposure it's harmful to health of workforce. Experience various pressure conditions both from chemical, physical, biological and psychic. One of the pressure conditions is work environment with a hot working climate cause physiological and psychological disorders so that it can cause diseases due to work and work accidents that have an impact on decreased work productivity. ${ }^{(10)}$

Measurement of body temperature in oral using an oral thermometer. Measurements are taken at the beginning of work, when the workforce is at work, and after work. Oral temperature is lower than $0.6^{\circ} \mathrm{C}$ than the core temperature of the body. Weight monitoring can be done by measuring weight with bathroom scale. Weight measurements are taken at the beginning of work and after exposure to heat pressure. Lack of this method is when doing weight measurement in the bathroom scale, labor must wear underwear only, because to avoid measurement inaccuracies due to the weight of sweat absorbed by clothing in order to accurate results .

Overweight or obesity can affect a person affected by heat related disorders. An obese person has a 3.5 times risk of developing the disease due to heat pressure. Weight gain will require more energy to do activities so it will require more oxygen as well. The fat layer will inhibit the transfer of heat from the muscles to the skin. So when a person with a high body mass index receives heat pressure will have a high risk of experiencing heat strains due to the inhibition of the process of transfer of heat from the body to the skin. ${ }^{(11)}$ Workers over the age of 40 should not be placed in hot workplaces because sweat glands show a slower response to metabolic heat loads and hot environments. ${ }^{(1)}$ Ability tolerate to heat will decrease as get older. The condition more it feel real when age reaches 40 years, so ability of body to cool down through evaporation of sweat becomes slower. 40 years old period at workers, body's process for producing sweat is much slower than younger workers. ${ }^{(12)}$

Analysis conducted in South Africa's gold mining for 5 years showed an increase in cases of heat strains as workers increased lifespan. Older person ages response to heat will be difficult due a decrease in heart efficiency. In addition, the older difficulty of sweating thus reducing ability to lower body's core temperature. Cases of heat strain per 100,000 workers are 10 times greater in men over the age of 40 than men under the age of 25 whose decreased amount of bodily fluids is a factor that may lead to high cases of fatal and non-fatal heat strains in older groups ${ }^{(5)}$.

Purpose of this study was to examine the influence of age and nutritional status on heat strains incident on worker of Brem Making in Kaliabu village, Madiun district.

\section{METHOD}

This research was observational study, with cross-sectional design. Criteria of research workers on brushing, harvesting, stirring, printing and drying section in brem industry of Kaliabu Subdistrict, Madiun Regency, East Java, Indonesia. Start from October to March 2020 with sample 266 workers, taken with "simple random sampling" technique. It had criteria of inclusion and exclusion proposed as follows: 1) inclusion: a. Brem Industries (Operation more than 1 year, working $>8$ hours/day,actively producing daily), b. Worker (willing be respondent, age 20-50 ${ }^{\text {th }}$ years, working period $>1$ years, not have infection or surgery at ears, work 7 days without holiday), 2) exclusion: a. worker sick or treatment, b.worker have history about hypertension or hypotension. Variables consisted of exogenous: health status and age. Endogen variable was heat strain. Data from all variable collected with questioners and instrument research usd observation, measurement, interview and documentation; then analyzed using path analysis with Amos 23.

\section{RESULT}

Based on table 1 distribution of age variables from 157 respondents, respondents aged 41-50 years as many as 116 people $(73.9 \%)$.

Table 1. Age distribution

\begin{tabular}{ccc}
\hline Age & Amount & Percentage \\
\hline 20 - 30 Tahun & 7 & 4.5 \\
31 - 40 Tahun & 34 & 21.7 \\
41 -50 Tahun & 116 & 73.9 \\
\hline
\end{tabular}

Tabel Distribution of nutritional status

\begin{tabular}{cccc}
\hline IMT & Nutrition Status Category & Amount & Percentage \\
\hline$<17.0$ & Skinny Weight Level & 0 & 0 \\
$17.0-18.4$ & Skinny Light Level & 0 & 0 \\
$18.5-25.0$ & Normal & 91 & 58 \\
$25.1-27.0$ & Mild Level Fat & 55 & 35 \\
$>27.0$ & Weight Level Fat & 11 & 7 \\
\hline
\end{tabular}


Based on table 2 distribution of nutritional status of 157 majority had normal nutritional status of 91 respondent $(58 \%)$.

Table 3. Heat strain distribution

\begin{tabular}{ccc}
\hline Heat strain levels & Amount & Percentage \\
\hline Not experiencing heat strains & 15 & 9.6 \\
Low category heat strains & 134 & 85.4 \\
Medium category heat strains & 8 & 5.1 \\
High category heat strains & 0 & 0 \\
Heat strain category is very high & 0 & 0 \\
\hline
\end{tabular}

Based on table 3 distribution of heat strain frequency from 157 respondents majority respondents with low category Heat strain events as many as 134 respondents $(85.4 \%)$.

Results of data analysis using Amos 23 software obtained the following results:

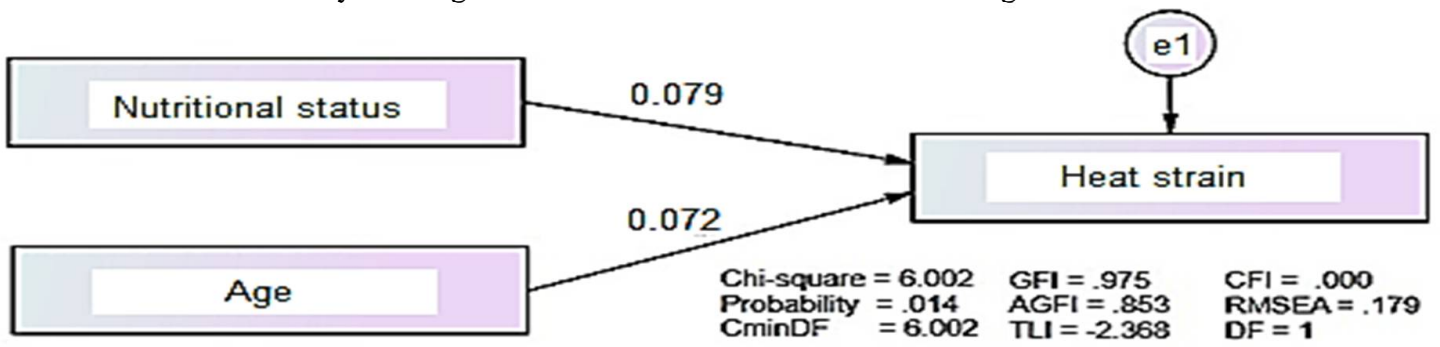

Figure 1. Path analysis result

The Chi-square value was 6.002 , probability $=0.014, \mathrm{CminDF}=6.002, \mathrm{GFI}=0.975, \mathrm{AGFI}=0.853$, TLI $=-2.368, \mathrm{CFI}=0.000, \mathrm{RMSEA}=0.179$ and $\mathrm{DF}=1$. Where the value of Standarized regression of weight nutritional status against heat strain was 0.079 and variable age against heat strain was 0.072 .

\section{DISCUSSION}

Results obtained from regression analysis in examining the influence of variable age and nutritional status on heat strain events in workers at Brem Industries industry at Kaliabu Village, Madiun District. Statistical test results using SPSS AMOS 23 showed that age variables affect heat strain event variables with model $\mathrm{P}$ significance of 0.014 below alpha value (0.05) and large influence based on Estimate Standarized Regression of Weight feature shows positive number (0.072) which means the risk of heat strain event variable will increase by 0.072 times from the increase of age variable. Related variable nutritional status to heat strain events using SPSS AMOS 23 shows that the nutritional status variable affects the heat strain event variable with a $\mathrm{P}$ model significance level of 0.014 below alpha value (0.05) and the influence based on the Estimate Standarized Regression of Weight feature shows a positive number (0.079) which means the risk of heat strain event variables will increase by 0.079 times from the increase in nutritional status variables. ${ }^{(13)}$

Age variables have a significant influence on heat strain events. Majority of workers aged between 41-50 years old are 116 people (73.9\%). Body's tolerance to heat decreases with age due to decreased blood flow to the skin to release heat from the body to the environment. So that the temperature in the body will quickly increase and support the occurrence of heat strains in a person. ${ }^{(4)}$ Heat Strain Elderly During Waves In The Netherlands where the study examined the elderly related to the incidence of heat strains but especially in the elderly. ${ }^{(14)}$

Study examined 8 elderly people using hildago system application related to monitoring heart rate, temperature to respiratory level. After being observed for days, the results were obtained that the heat strain event is closely related to age. age is one of the factors that affect the body's susceptibility to heat pressure. Workers over the age of 40 should not be placed in hot workplaces because their sweat glands show a slower response to the metabolic heat load of the environment. ${ }^{(15)}$ The assumption of the researchers is that because the heat strain events adjust to the environment, the older the age, the process of adjustment to the environment is also reduced in tackling the surrounding environment.

Variable status of nutrition also has a significant influence on the incidence of heat strains. This was supported by the results of research in the work environment in the brem industry in Kaliabu Village, Madiun from 157 respondents who had normal nutritional status of 91 people (58\%), respondents who had light-level fat nutrition status of 55 people (35\%), and respondents who had a nutritional status of 11 people (7\%). Obesity can increase the risk of heat strains when working in a hot environment. Based on regression weight results explain the influence of nutritional status on heat strains. The validity of the data can be seen from the calculation of spss statistical tool AMOS 23 shows probability level value shows a sign of 0.077 which means the effect shows a level of significance below 0.05 or can be said to have a significant effect. ${ }^{(14)}$ 
Obesity is one of factors that influence the occurrence heat strains. Ability to release heat from the body directly affects body mass. Body composition will affect increase in body temperature. A person with a greater body mass, his body temperature will increase faster so that the risk of experiencing heat strains also increases. Based on table 4.3, work environment at brem industry Kaliabu Village, Madiun District from 157 respondents who have normal nutritional status of 91 people (58\%), light-level fat nutrition 55 people (35\%), and fat-level 11 people (7\%). Heat strains occurred most in groups with obesity status and had a higher body temperature, pulse rate and dryness compared to the group with skinny body mass index status. ${ }^{(5)}$

\section{CONCLUSION}

Conclusion about research is that age and nutritional status have a significant influence in the incidence of heat strains in workers. Advice industrial owner may can install adequate ventilationand exhaust fan for fresh air, socialization about health nutritions with consultans, provide information about sign and symptoms about heat exposure with poster in work area and counselling to worker and corporate with Health Department every 6 month related health facilities for them. Owner can consider about length and rest hours and elderly worker ot be placed hot environment or do rotation it. Worker must activity like maintain health life style with consuming vegetables and fruit. Drinking water is important for them, caused they work at hot environment and heavy workloads, so it recommended drink at least $2.8 \mathrm{~L}$ (equivalent 12 glasses with measure $240 \mathrm{ml}$ ). Worker with light workload recommended drink $1.9 \mathrm{~L}$ (equivalent 8 glass with measure $240 \mathrm{ml}$ ) and every 30 minutes drink $250 \mathrm{ml}$ without waiting thirst, if needed. Nutrition/calorie regulation accordance with worker activities. Control intake by doing a balanced nutrition diet method. Sport activity like jogging or other with exercise and regularly. Department of Manpower and Transmigration, Department of Industry Trade and Mining also Department of Health Madiun district can conduct coaching and supervision of workers in Occupational Health and Safety. Counseling and socialization about dangers of accidents and diseases due to work and what things are needed for working in hot environments.

\section{REFERENCES}

1. Larranaga MD. Applied Physiology of Thermoregulation and Exposure Control. Dalam Occupational Environment: Its Evaluation, Control and Management $3^{\text {rd }}$ Edition. Editor D.H. Anna. Amerika: AIHA;2011

2. Dehghan H, Ehsanollah H, Peymaneh H. Validation of Questionnaire for Heat strain Evaluation in Women Workers. Iran: Isfahan University of Medical Sciences; 2013.

3. Parameswarappa SB, Narayana J. Assessment of Heat Strain among Workers in Stell Industry. India: Department of Environmental Science Kuvempu University; 2014.

4. Dang, Bich N. Factors Associated With Heat Strain Among Workers at an Aluminum Smelter in Texas. Journal of Occupational and Environmental Medicine. 2014;56(3):313-8.

5. Fadhillah R. Faktor-Faktor yang Berhubungan Dengan Heat Strain Pada Pekerja Pabrik Kerupuk di Wilayah Kecamatan Ciputat Timur. Skripsi. Jakarta: UIN Syarif Hidayatullah; 2014.

6. Ningsih SN, Nilamsari N. Faktor Yang Berhubungan Dengan Kelelahan pada Pekerja Dipo Lokomotif PT Kereta Api Indonesia. Journal of Industrial Hygiene and Occupational Health. 2018;3(1):69-82.

7. Artha DP. Gejala Heat Strain Akibat Paparan Panas pada Pekerja di Pabrik Tahu Sumedang Kecamatan Medan Polonia Tahun 2015. Skripsi. Medan: Program Studi S1 Kesehatan Masyarakat, USU; 2016.

8. NIOSH. Criteria for a Recommended Standart: Occupational Exposure to Heat and Hot Environments. United State America: National Institute For Occupational Safety and Health; 2016.

9. Occupational Safety and Health Administration. Heat stress: Defining, Evaluating and Preventing. Amerika Serikat: Occupational Safety and Health Administration; 2012.

10. Suma'mur PK. Higiene Perusahaan dan Kesehatan Kerja. Jakarta: Sagung Seto: 2014.

11. Kenny, Glen P, Jane Yardley, Candice B. Heat Stress in Older Individuals and Patiens with Common Chronic Diseases. National Center for Biotechnology Information; 2010.

12. Nawawinetu ED. Modul Kuliah Heat Stress. Surabaya: Universitas Airlangga; 2010.

13. Ramayanti R. Hubungan Status Gizi dan Beban Kerja terhadap Kelelahan Kerja (Studi pada Tenaga Kerja PT. Hikmah Sejahtera Bagian Catering Hikmah Food Surabaya. Skripsi. Surabaya: Universitas Airlangga; 2015.

14. Daanen H, Heusinkveld B, van Hove B, van Riet N. Heat Strain in Elderly During Heat Waves in Netherlands. 2011;168-170.

15. Istiqomah FH, Nawawinetu ED. Faktor Dominan yang Berpengaruh Terhadap Munculnya Keluhan Subjektif Akibat Tekanan Panas Pada Tenaga Kerja di PT. IGLAS (PERSERO)). Indonesian Journal of Occupational Safety and Health. 2013;2(2):175-184. 